DOI: 10.21625/resourceedings.v2i3.652

\title{
Renewed spirituality in cloistered architecture in Naples
}

\author{
Ornella Zerlenga ${ }^{1}$ \\ ${ }^{I}$ Università Degli Studi Della Campania 'Luigi Vanvitelli', Department of Architecture and Industrial Design
}

Email: ornella.zerlenga@gmail.com

\begin{abstract}
The object of study is the cloistered architecture with particular attention to the cloisters of Santa Maria della Sanità and San Severo in Naples. Among the different environments that characterize a convent or monastery, the cloister is the main element of religious life, the central nucleus of the activities carried out collectively. Typologically, the distinctive features of the cloister can be identified in the following: position within the religious complex; presence of porch, garden, well; variety of shape and planimetric dimension. The cloister of Santa Maria della Sanità has an unusual ovate shape. This cloister was severely tampered with by the construction of the bridge of Sanità in the French decade. This intervention brought the cloister into oblivion and decay like that of San Severo. Recently the cloisters have been restored to new social use to promote inclusion and diversity.
\end{abstract}

(C) 2019 The Authors. Published by IEREK press. This is an open access article under the CC BY license (https://creativecommons.org/licenses/by/4.0/).

\section{Keywords}

Cloistered architecture; church of Santa Maria della Sanità in Naples; church of San Severo in Capodimonte; architectural and environmental survey; ovate cloister; graphic analysis

\section{The architecture of the cloister}

In general, the 'cloister' is the courtyard of a monastic or convent complex, intended for seclusion and characterized by an open space surrounded by arcades. The word 'cloister' derives from the Latin claustrum, which means 'closure', 'closed place'. The opportunity to endow the religious complexes of the cloister with the western cenobitic rule is based on the institution of small collectives gathered around spiritual fathers. In this sense, the cloister is identified with a connective space equipped with covered corridors, whose circumscribed configuration also welcomes activities carried out in common areas, collected and/or separated from the outside such as meditation, reading, walking. It is probable that this space referred to the 'Heaven' (from the Persian pairidaeza, 'fenced-in place'; in Greek, 'garden'; from the Latin, paradisus), a quadrangular porticoed courtyard overlooking a paleo-Christian basilica for education of the catechumens and equipped with cantaro or fountain for ritual ablutions or architectural typologies prior to Christianity such as the atrium and the peristylium of the Roman and Italic domus. Among the different environments that characterize the religious complex, the cloister is the main element around which church, refectory, chapter, library, study rooms and cells gravitate, as documented in the ancient iconographic source of the monastery of San Gallo (820). The position of the cloister with respect to the complex is not fixed but conditioned by the monastic rule, which determines the internal or external location of the religious settlement with respect to the inhabited center: greater urban isolation and search for sites with a remarkable landscape value and cloisters with panoramic views (Benedictine rule); integration between religious and secular communities with settlement patterns within the urban center and closed cloisters to often protect their enclosure (reforming and begging rule). 
The cloister is therefore an excellent architecture, whose distinctive features refer to the original memory. Therefore, the danger of transformation interventions that severely compromise the identity of the cloister must be pointed out, which in some cases are more vague than the state of abandonment in which many pay.

\section{Distinctive features of the cloister}

Typically, the design module (which generates the spatial configuration of the cloistered system) is the span (from 'field', limited surface), the surface between the vertical axes of two successive supports or the portion of space delimited by arches of vault (arches arranged perpendicular to the direction of the porch). The recurrent planimetric configuration of the cloister is regular with a square or rectangular shape, generated by the succession of bays with a square or rectangular plan. The cloisters with only three sides are rare while those with a circular or transgressive perimeter with an ovate shape are exceptional events: in Naples, the oval cloisters of Santa Maria della Sanità (here under study) and San Tommaso d'Aquino (now demolished ), both by the Dominican friar Fra' Nuvolo; in Spain, that of the church of Sant Antoni. Moreover, the important local settlements can present a double or triple number of cloisters (including Santa Maria della Sanità).

The planimetric dimension of the cloister is variable, starting from a minimum number of one span per side until reaching cloisters with several spans per side greater than ten. The porch, the covered perimeter space, is one of the most representative distinctive elements of the cloister, being able to appear sober or redundant due to spatial configuration and use of materials and, in cases of significant importance, the cloister can also present a double-order porch superimposed. In general, the cloister is characterized by the presence of an overlying plane, aligned or set back, more rarely in the number of two. In the first case, the front is articulated by the succession of frontal arches and overlying windows, which illuminate the upper floor and may or may not present a vertical alignment with the underlying arches. In the second case, the floor above the porch is set back, guaranteeing greater insulation to the environments of the second level. In general, the parapet of the upper floor is in continuous or variously perforated masonry or has a balustrade. In general, the porch is bounded on the outside by a series of vertical supports, columns or pillars, characterized by the presence of capitals and often resting on a high plinth called podium, an interrupted seat near the main accesses to the central uncovered space or in each span. In the continuous inner wall, there are the access rooms to the different rooms of the religious complex, variously characterized by the presence of stone portals. Often, the interior walls are decorated with pictorial apparatuses and present plaques, tombstones, niches to remember events. In most cases, the roof of the porch consists of a vaulted system, whose structural form varies from the simplest barrel vault to the more complex vaulted, cross vaulted, spherical vaulted nails. The arches of the vaults vary according to the guiding curve (round, sharp; lowered; polylobate; etc.) and for the different decorations of the same. The open space of the cloister, located at the same level as the porch or slightly subjected to a few steps, is usually used as a garden with low flowerbeds or tree species of a local nature (mainly citrus) or paved with paving stones or cobblestones. Generally, a geometric design configures the paths for walking and channels for the outflow of rainwater. Another characteristic element of the cloister is the well which, connected to the cistern below, is often located in the center of the open space or in a lateral, sometimes angular position. The well, generally in stone material, can take on different types (with a circular, square, polygonal, uncovered or covered structure that is 'aedicula', etc.) as well as the structural solutions supporting the winch, including materials used for it (marble, wrought iron, etc.). For all these reasons, despite having limited dimensions, within the design culture of the cloister the well constitutes a further occasion for significant artistic expression (Zerlenga, 2000).
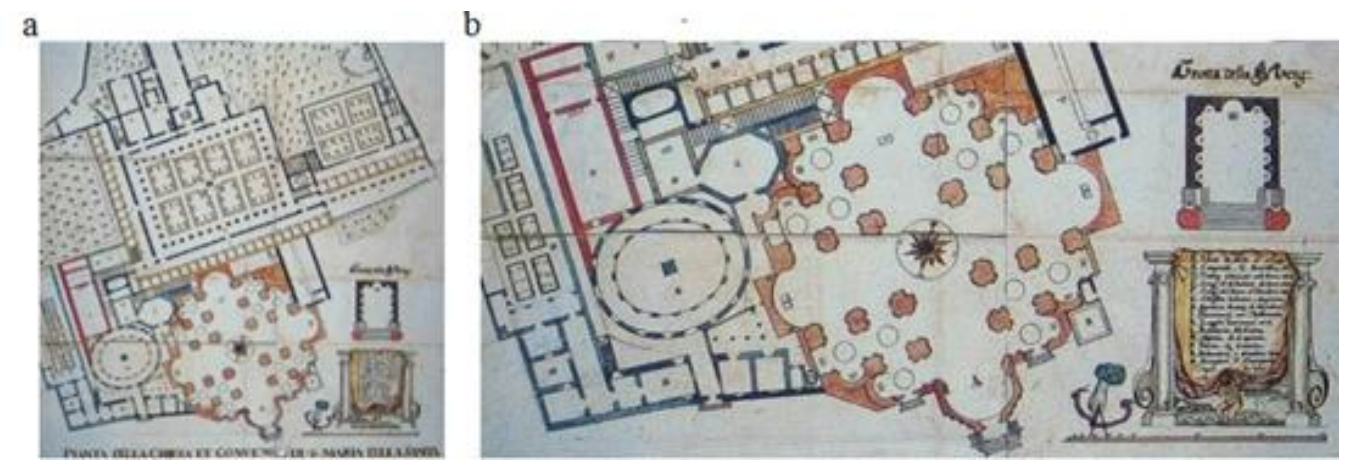

Figure 1. (a) Maiorino, convent of Santa Maria della Sanità, 1715; (b) Detail of the ovate cloister. 


\section{The convent complex of Santa Maria in Naples}

The church of Santa Maria della Sanita in Naples (also known as the church of San Vincenzo alla Sanita) was built on the catacombs of San Gaudioso. Work began in 1577 while the church was built between 1602 and 1610 by the architect and friar of the Dominican preacher's order, Giuseppe Nuvolo. Construction work on the main dome ended in 1613; the bell tower was erected between 1612 and 1614. In 1725 Gaetano Massa covered the dome with majolica in yellow and green. The original configuration of the monastery of Santa Maria della Sanita is documented in a plan preserved in the State Archives of Naples. It is a copy of Giuseppe Nuvolo's project, written in 1715 by Maiorino (Fig. 1a). This plan is particularly important because it represents the entire monastic complex, consisting of the Greek cross church, two cloisters and numerous other rooms. Given the uneven orographic configuration of the place, the project of the convent complex is developed on two different levels: the lower one, at the level of the current Piazza della Sanita, which leads to the church and to the ovate cloister, called "lower"; the upper one, at the current, where the rectangular cloister was erected, called "upper", the cells and other rooms. The construction of the oval cloister dates to the late 16th century and constitutes a significant transgression of the monastic rule, finding a similar example in Spain with the oval cloister of the church of Antoni de in Palma de Mallorca. The oval cloister of Santa Maria della Sanita is divided into a series of arches on pillars and vaults, whose monochrome fresco decorations were executed in 1624 by Giovanni Battista di Pino and depict some episodes on the stories of the Dominican order. In Maiorino's plan it is possible to trace the geometric construction used in tracing the ovate profile of the cloister, corresponding to the fourth rule indicated by Sebastiano Serlio in his treatise on civil architecture (Zerlenga, 1992). In the early nineteenth century, with the advent of Napoleon and the consequent suppression and expulsion of the monastic order, in 1809 most of the monastery was demolished to create the road desired by Giuseppe Bonaparte to more easily reach the Capodimonte Palace. The oval profile of the cloister was seriously disfigured by two pillars of the bridge of Sanita, today the Maddalena Cerasuolo bridge. The bridge was built in tuff with six bays, about $21 \mathrm{~m}$ high and about $120 \mathrm{~m}$ long. Towering over the neighborhood, the bridge now links two important city streets, Via Santa Teresa degli Scalzi and Corso Amedeo di Savio, originally named with the only name of Corso Napoleone. With the construction of the bridge, the rhythm of the cloister portico was interrupted (Fig. 2a, b) and the district isolated from the city (Zerlenga, 1991).

a

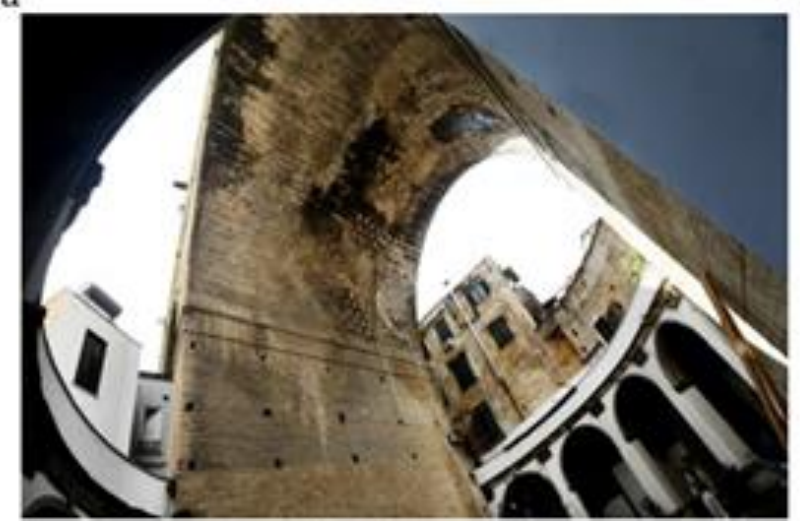

b

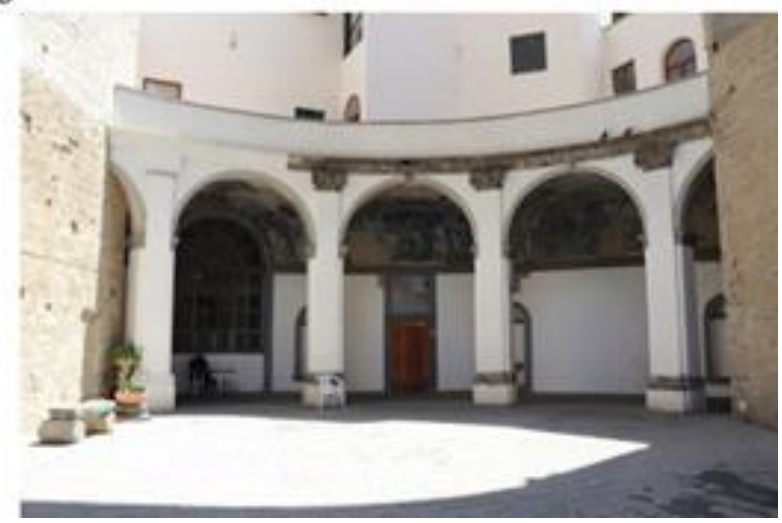

Figure 2. (a) The bridge over the cloister of SantaMaria della Sanità; (b) The ovate cloister between the pylons of the bridge ofSanità.

In addition to the oval cloister of the monastery of Santa Maria della Sanità, fra' Nuvolo built another ovate cloister in Naples, inside the conventual complex of San Tommaso d'Aquino which, located between the present via Medina and via Toledo, was demolished for construction. of the buildings of the Intendancy of Finance and of the Banca Nazionale del Lavoro. Also this cloister was frescoed by Giovan Battista di Pino and, after the landslide of 1656, was re-cooled by Andrea Viola and Nicola Vaccaro (Galante, 1872). In this sense, despite the damage suffered, even today the oval structure conferred by the architect Fra' Giuseppe Nuvolo on the cloister of Santa Maria della Sanità returns this architecture as unicum in Naples and, specifically, in Italy (Campi, 2007). 


\section{The architectural and environmental survey of the ovate cloister}

In 2018 the architectural survey of the ovate cloister of the church of Santa Maria della Sanità began according to the current state which, after the recent restoration, returned it to new use. The significant operations were completed in March 2019 and involved not only the architecture of the cloister but also the nineteenth-century construction of the bridge of Sanità, as well as the numerous buildings, which lean against the oval perimeter of the cloister. According to the iconographic source of 1715 (Fig. 1b), the ovate cloister was located at the lower level of the valley of Sanità. The cloister was accessed from the road (now Via Arena alla Sanità) along the direction of the minor axis of the oval and, still in this direction, the monumetal staircase leading to the upper level of the tuff bank was accessed (about 20 $\mathrm{m}$ ), on which the remaining part of the convent had been built. Along the cloister's ovate perimeter there were connections to the church, the sacristy and the Treasury of the Saints. Martyrs (1633), the Congrega del Rosario (1624) and La Speziaria, where they sold medicinal herbs grown in the garden. The first operation returned four floor plans of the cloister to the levels of the ground floor, first and second floor and roof. In reality, the original design of the cloister involved only one altimetric level but, over time, additional buildings were built around its perimeter. Recently, some of these environments have been transformed by the well-known Neapolitan designer Riccardo Dalisi into the B\&B La Casa del Monacone, a welcoming project in the Sanità neighborhood managed by the La Paranza cooperative. The last planimetric level (at $21 \mathrm{~m}$ ) returns instead the view from above of the current spatial configuration of the cloister, overpassed by the bridge of Sanità (Baculo, 2006). The construction of the Sanità bridge has greatly changed the visual perception of the ovate cloister, both in height and in plan. The original geometric structure was inspired by a double symmetry, bilateral and orthogonal, along the minor and major axes of the ovate profile and the spans, of isosceles trapezoidal shape to follow the ovate shape of the profile, were in number of 16. With the construction of the bridge, the geometric symmetry and the number of spans are no longer perceptible as the longitudinal direction of the bridge rotates about $30^{\circ}$ clockwise with respect to the minor axis. Furthermore, the two pylons of the bridge inside the cloister affected the northern section of the cloister, destroying three bays, while on the southern one the lower corner of the pylon demolished one of the cloister pilaters and interrupted the perspective view of the cloister, previously perceived by the androne access (Fig. 3a, b, c). Overall, this has led to a new perception of use of the cloistered oval space, dictated by the new directions of bridge development, longitudinal and transverse. In fact, the cloister is no longer perceived as 'open-air' but almost like a closed space covered by the under-arch of one of the 6 arches of the bridge of Sanità, whose height at the intrados of the vault is higher than that of the cloister more of $2 / 3$. This new visual perception has considered the new social use of the cloister so much so that the multiple cultural representations, which take place in it, find as a stage backdrop the brick front of the northern pillar with respect to which the seats are arranged (Fig. 4a).

a

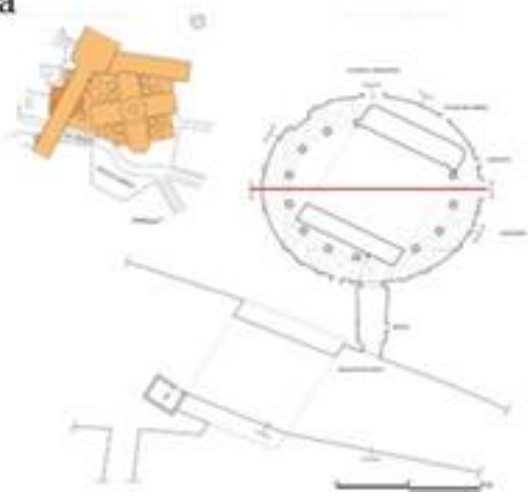

b

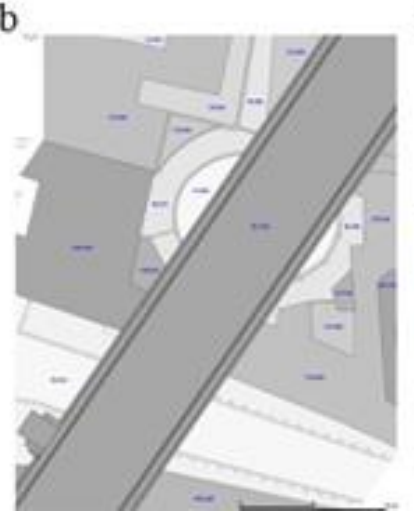

$\mathrm{c}$

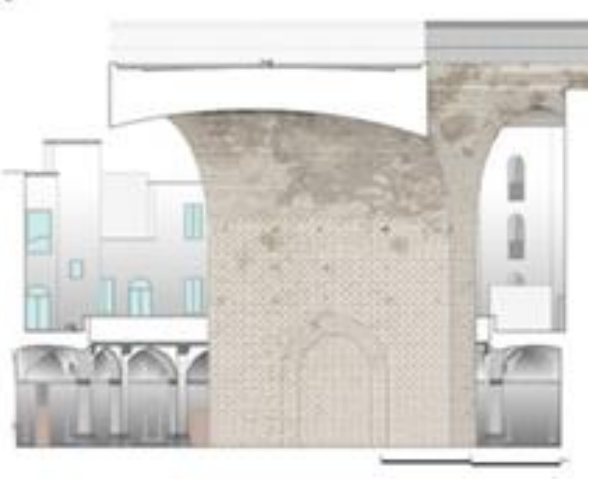

Figure 3. (a, b) Planimetric survey of the cloister of Santa Maria della Sanità;(c) section on the bridge in the ovate cloister.

\section{Today: the cloisters and the San Gennaro Community Foundation}

The ovate cloister of the church of Santa Maria della Sanita remained abandoned for years until the parish activity of don Giuseppe Rassello, first, and don Antonio Loffredo, then, did not bring to the fore the architectural resources of the ancient disused cloister Therefore, the cloister and adjoining rooms have been identified as opportunities to promote social inclusion and diversity, renewing the spiritual awareness of one of the most degraded neighborhoods in the city. The recently restored ovate cloister has become a meeting place and cultural activity (musical and theatrical 
performances, film screenings), including the recent presentation of the book by Chiara Nocchetti, Vico esclamativo. Voci dal rione Sanita. Debating the juvenile deviances and the need to find new models of aggregation to respond to the violence of the baby gangs, the parish priests listened to the dreams of the inhabitants of the neighborhood and, above all, of the boys, who wanted a place where they could "throw punches". The sporting discipline of boxing has appeared as the best opportunity to respond to the demands of the boys, remove them from the street and channel their energies into sport. Initially, the open space of the ovate cloister had already been equipped to carry out this activity at the time of Father Rassello. Subsequently, Don Antonio Loffredo (with the Comunità San Gennaro and the L'Altra Napoli onlus) asked for the collaboration of the Naples Police Headquarters, the Fiamme Oro sports group and the Italian Boxing Federation. Temporarily and with the permission of the Curia of Naples, the boxing gym for the boys was set up in some spaces annexed to the oval cloister such as the Treasury Room and the Sacristy. At the inauguration (10 July 2018), the instructors were the champions of gold and silver of the Fiamme Oro (including the Olympic gold Roberto Camerelle), who taught boxing to the boys to turn anger into good energy. The opinion was: "boxing is a sport of social inclusion, which teaches healthy values such as legality". These sacred spaces have been renewed in symbolic value and transformed into opportunities to promote spiritual spaces in which to form the character of children. The aim is to show that there is a different path from the criminal one.

The definitive gym will have to open in the cloister of the nearby church of San Savero. This cloister appears today very degraded and with superfetations that have strongly altered the original integrity (Regina, 2004). The cloister belongs to the institute Federico Antonio Ozanam (1813-1853), a French historian and journalist and a Catholic apologist among the main exponents of the neocattolic movement in France, founder of the Society of Società San Vincenzo De Paoli and beatified by Pope Giovanni Paolo II in 1997. Reinterpreting the forms of the cloister of the monastic complex of San Severo, the geometric relationships and the symbolism of the Christian tradition, the project of the gym for boxing will give new life to the neighborhood and the cloister. Called LuxBox, the social reuse project involves the construction of a light box, in white steel and large windows, resting in the center of the cloister (Fig. 4b). According to the designer, the architect Nicola Flora, due to its symbolic vocation, the box will bring light to the whole neighborhood, calling kids, children and entire families to experience the new complex for the whole day. As for the most advanced European cultures, the redeemed cultural good lives a new life thanks to the encounter with the contemporary and the neighborhood in which it lives. In this sense, in the Health district the LuxBox project could lead to the creation of a new Free Entry Citta del Bello, as already happened for the recovery of the internal spaces of the Consiglio basilica in Capodimonte and destined to become a center for children with disabilities.

a

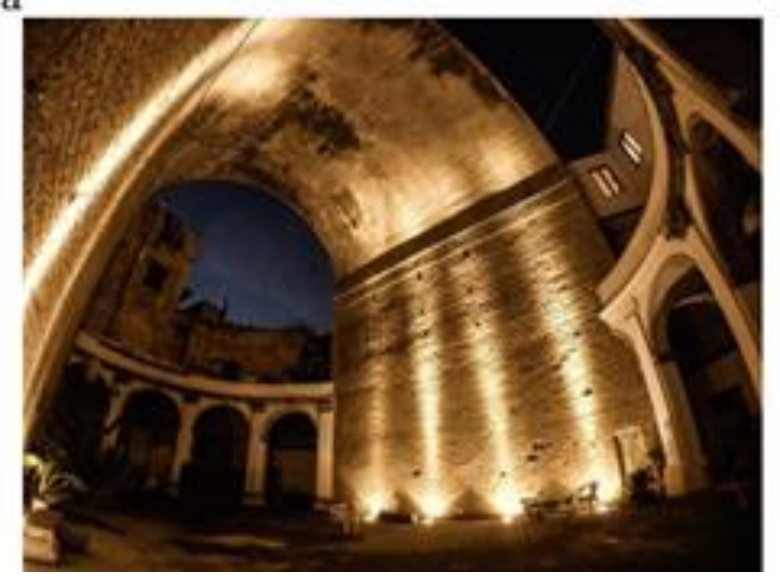

b

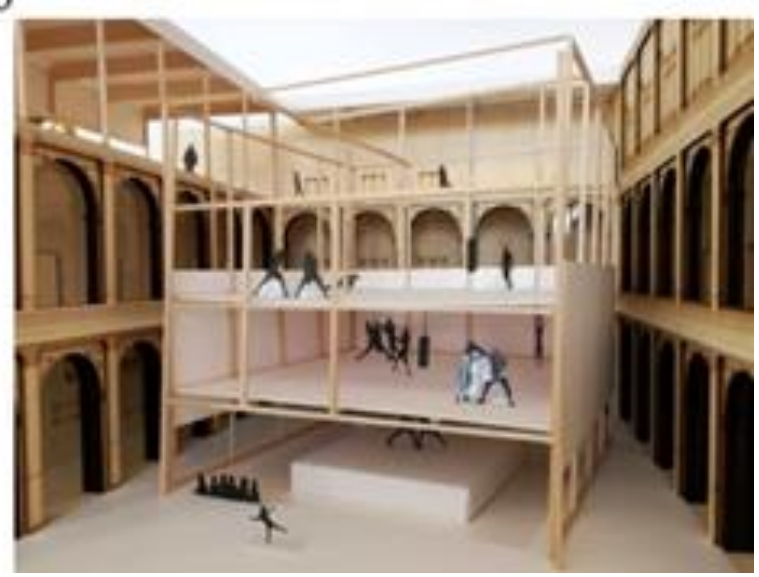

Figure 4. (a) New layout of the cloister of Santa Maria della Sanità; (b) LuxBox in the cloister of San Severo inCapodimonte.

\section{Conclusions}

From a general point of view, this contribution demonstrates how the sacred space of the cloisters of the churches of Santa Maria della Sanita and San Severo in Capodimonte (long deprived of any function) has been reinterpreted as an opportunity for renewed spirituality to promote social inclusion and the diversity. These projects, in fact, appear to be aware of the innumerable needs and emerging new poverty in the Health district, and, therefore, move in the opinion that to activate virtuous processes it is necessary to engage in the formation of the new generations. From the 
disciplinary point of view, the operation of survey and representation of the ovate cloister of Santa Maria has demonstrated not only the need for a good practice in the formulation of the data collection and return processes (Docci, Maestri, 1984) as much as a critical approach capable of governing processes, reading material sources (architecture and urban context), intersecting them with documentary ones (archival, bibliographic, iconographic, photographic) to formulate project hypotheses that respect traces of ancient memory and new needs of contemporaneity.

\section{References}

Baculo, A. et al. (2006). I fronti urbani di Napoli. I quartieri degradati e le piazze della città. Napoli: Electa.

Campi, M. et al. (2007). I chiostri di Napoli. Rilievo/Rappresentazione/Rivalutazione/Riqualificazione. Napoli: Arte Tipografica.

Docci, M., Maestri, D. (1984). Il rilevamento architettonico. Storia, metodi e disegno. Roma-Bari: Laterza.

Galante, G.A. (1872). Guida sacra della città di Napoli. Napoli. Fibreno.

Regina, V. (2004). Le chiese di Napoli. Viaggio indimenticabile attraverso la storia artistica, architettonica, letteraria, civile e spirituale della Napoli sacra. Napoli: Newton e Compton.

Zarlenga, O. (1991). Santa Maria della Sanità: dall’ultimo esempio di architettura claustrale a pianta ovata al primo segno della città laica. In: Buccaro, A., editor. Il borgo dei Vergini. Storia e struttura di un ambito urbano. Napoli: CUEN, p. 199-209.

Zarlenga, O. (1992). Fra Nuvolo e la ovo similis. XY. Dimensioni del disegno, 13:73-85.

Zerlena, O. (2000). Regola e trasgressione nell'impianto claustrale. In: Margiotta, M.L., editor. Il giardino sacro. Chiostri e giardini sacri della Campania. Napoli: Electa, p. 73-78, 179-190.

\section{Acknowledgment}

The survey and the representation of the ovate cloister of the church of Santa Maria della Sanita and of the bridge of the Sanita was realized in 2018-19, respectively, by Imma Izzo and Ivano Signore with the scientific coordination by Ornella Zerlenga and technical-graphical by Vincenzo Cirillo. Thanks to Antonella di Luggo, Nicola Flora, Francesco Marino, don Antonio Loffredo, Massimo Cuomo and the Fondazione di Comunità San Gennaro Onlus for the Memorandum of Understanding signed in March 2019 with the Department of Architecture and Industrial Design of the University of Campania Luigi Vanvitelli for common research on cultural growth in the context of the Third Mission. 